\title{
Analysis on Locke's Thoughts in Declaration of Independence
}

\author{
Fulin Yang \\ College of Political Science, Baoshan University, Baoshan, 678000, China
}

\begin{abstract}
Keywords: Declaration of Independence; Locke; separation of powers
\end{abstract}
\begin{abstract}
As the basis of American Constitution of 1787, the Declaration of Independence was published on July 4, 1776. This day becomes American Independence Day (commonly known as National Day). The publishing of Declaration of Independence is the beginning that America became independent and then it was founded. However, the theoretical thoughts in Declaration of Independence are closely related to British modern liberalist Locke. The separation of powers, right theory, including right to life, right of freedom and right to seek for happiness, even origin theory of limited government, all come from Locke's thoughts. Locke's Two Treatises of Government can be called origin of thoughts of Declaration of Independence.
\end{abstract}

\section{Introduction}

As the basis of American Constitution of 1787, the Declaration of Independence was published on July 4, 1776. This day also becomes American Independence Day (commonly known as National Day). The publishing of Declaration of Independence is the beginning that America became independent and then it was founded.

\section{Locke's thoughts of separation of powers in the Declaration of Independence}

Although the Declaration of Independence is a very important and unofficial document similar to mobilization order before war, various kinds of resentments to British colonists it shows and the way of describing government presuppose the mode of separation of powers. [1] This kind of theory of separation of powers was a kind of theory very popular in continental Europe and England (American colonists) at that time. The Declaration of Independence has mentioned God for 4 times. This is the first time that the God is regarded as lawmaker, and this situation may happen again. It is the God that arranges the order for all things on earth and stipulates the future of all things. That is to say, the God is firstly regarded as a lawmaker, and then regarded as a judge, and finally regarded as an administrator to protect the public and execute the formulated law, which also shows the distribution of executive power. [1]

It is obvious that the theory of separation of powers in the Declaration of Independence originates from Locke's thoughts of separation of powers. It can be even said that the main origin of thoughts of the Declaration of Independence is Locke's thoughts.

As the founder of modern western thought of liberalism, Locke's theory is all-inclusive. He developed and demonstrated western "man's natural right", and pointed out that "now that people are equal and independent, any person shall not damage others' life, health, freedom or property, and those are human beings' inalienable natural rights. Same as other enlightenment thinkers, Locke also used "social contract" to explain the origin of country and government. Meanwhile, in order to limit the power of government, Locke thought that the most effective way to prevent abuse of powers was separation of powers. He advocated to divide state powers into legislative power executed by parliament and executive power and foreign power executed by monarch; the former power was the supreme power, and it controlled the latter two powers.

(I) The legislative power is especially important.

The legislative power originates from people's transfer and abandoning of powers; for example, "under this condition, they are willing to give up punishment power they independently execute, and deliver this right to one appointed person among them to exclusively execute it; furthermore, such power shall be executed according to rules unanimously agreed by the society or agreed by the 
authorized representative for this purpose; this is original power of legislation and executive power, and their cause, and the origin of government and society also lies at this point." [2] As for the work purpose of legislative power, Locke also made detailed description. "The person who masters the national legislative power or supreme power shall make governance according to established, well-known, and effective laws rather than temporary orders; the disputes shall be settled by impartial judges according to those laws; those powers are the social strength used in order to internally enforce the law, externally prevent or claim reimbursement for damage caused by foreign countries, and prevent society from being invaded." " All those powers are set for people's peace, safe, and public welfare." [2] As for position of legislative power, Locke thought that "the legislative power is not merely the supreme power of one country; once the community delivers this power to some people, it becomes sacred and unalterable; if there is no approval of legislative body selected and appointed by the public, any person' any order has no legal effect and enforceability no matter what form the order is given or what power provides support for such order.” [2]

(II) The executive power refers to a kind of power which people use to enforce the law.

The executive power is attached to legislative power; it is an auxiliary to legislative power, thus it is governed by legislative power. The executive power is set under legislative power, and it comes from entrusting of legislative power; therefore, the substance of executive power is also a kind of entrusted power. Because the legislative power is a power entrusted by the public, thus the executive power is a power entrusted by the public in essence. After making of law, in order to keep its continuous effect, there shall be an often existing power execution organ responsible for executing the formulated and effective law. No matter how perfect a law is, if it is not executed, everything will be in vain. It is unnecessary that the legislative body exists for a long time, but the executive organ must exist for a long time, for "the long-term existence of affairs related to enforcement of law determines this point. The political society is completely different from natural state. Under natural state, everyone is the executor with same power and can execute law for behavior violating against natural law. However, in political society, this executive power is delivered to the society rather than individual, and the violators shall be punished according to legal rules”. [6] Compared to individual power execution under natural state, the executive power has obvious advantages. Firstly, the fair execution can be ensured. The government's performance of executive power is for all behaviors violating against legal rules rather than specific individual, thus the impartial law enforcement due to personal gratitude or resentment is avoid. Secondly, the executive power has strong executive force. By comparison on government and individual, the individual is weak, but the government is recognized by the public and gathers all people's power, thus the execution can be more smooth and thorough. Finally, the personal randomness is avoided. The government's executive power is obtained according to legal rules, and there is a relatively clear standard; as for individual execution, each person has his or her own standard, and the disorder will happen.

(III) Foreign power "The foreign power refers to power related to solving war and peace, uniting alliance, and handling all affairs together for all foreign personnel and society, and it is similar to partial power executed by parliament and ministry of foreign affairs.” [3] Although Locke separates executive power and foreign power, their execution needs the power of whole society; it is unrealistic to forcibly separate these two powers and assign them to be mastered by different persons, that is, Locke thinks that it is hard to separate these two rights. The executive power is a domestic power, but the foreign power is an abroad power. There must exist exchange between one country with other countries, thus the foreign power is necessary. In Two Treatises of Government, Locke didn't discuss foreign power in details; however, in order for separation of powers, and checks and balances of powers, the foreign power shall be separated out. Locke thought that the foreign power is of vital importance, for the contact with other countries is a national affair. Locke was deeply aware of importance of foreign power, for he paid attention to spirit of contract. In foreign contact, no form of contract is signed with citizens of other countries, thus the contract which stands for spirit of freedom will lose effect under this condition. Furthermore, Locke was also aware of the importance of contact with other countries. In consideration of historical 
background in Locke's lifetime, the foreign contact and foreign trade had become an important task of one country. Due to awareness of importance of political, economic, and cultural contact with other countries, Locke thought it was necessary to make this power independent.

The theory of separation of powers in the Declaration of Independence is deeply influenced by Locke's theory of separation of powers. The drafter of the Declaration of Independence didn't deny this point.

\section{Locke's right theory and origin theory of government in Declaration of Independence}

The second paragraph of the Declaration of Independence proposes right to life, right of freedom and right to seek for happiness. "We think that all following truths are self-evident: all men are created equal; the nature endows them with several inalienable rights, including right to life, right of freedom and right to seek for happiness. In order to guarantee those rights, human beings establish government, and the proper right of government is produced under the approval of the governed. When any form of government has damage function on those objectives, people will have right to change or abolish it so as to establish a new government; the principles as foundation and way of organizational power shall make people think that it is able to make them obtain safety and happiness in this way. In order to be careful, the government which has been established for many years shall be not changed due to slight and temporary reason..." [4] This text mentions three kinds of important right, that is, right to life, right of freedom and right to seek for happiness. It is thought that those are people's most important rights, and it is further demonstrated that the government appears in order to guarantee people's these three kinds of rights.

Obviously, the right theory and theory about establishment of government in the Declaration of Independence are deeply influenced by Locke's thoughts. Locke thought that people have natural right to life, freedom, and property, and those rights are endowed by the God, thus it is unable to hand over those rights to another arbitrary power; the government is established in order to guarantee rather than damage those rights, thus the government can't obtain or re-assign property without permission. Locke's opinions about law are that the legislation is not for canceling natural law or natural rights, but for endowing law with deficient clear, accurate and fair implementation under natural state. The natural rights shall be reserved to restrict all people, "lawmaker is equal with others". The Declaration of Independence modifies property right in natural rights into "the right to seek for happiness"; however, in American people's heart, the natural rights still mean "life, freedom, and property". The law is formulated for the purpose of preventing government's abuse of power and guaranteeing people's natural rights.

In Locke's classic work The Second Treatise of Government, it is mentioned in the beginning that "... the political power is the right of law making to stipulate and protect property, the right to sentence to death and make lighter punishments, and the right to use the power of community to execute the law and defend the country against foreign invasion; all those things are for public welfare." [3] Locke takes "natural state" as historical premise, and specifies origin and purpose of state power through discussing property and property right, that is, "for people's peace, safety, and public welfare". The property mentioned by Locke not only refers to physical property, but also includes wider property such as life, health, and freedom. In this sense, the property becomes a kind of human beings' thing which can't be deprived by others.

In order to oppose Filmer's "divine right of kings", "hereditary of throne”, and other royalism theories and absolutism, Locke proposed theory of natural law and thought that human beings once lived under a kind of free and equal "natural state", and "under the natural state, there is a kind of natural law which everyone shall abide by to dominate this state”. Locke's property right is also a kind of natural right which conforms to natural law under natural state. Locke deduced natural law from natural state, and then deduced social contract theory from theory of natural law. In this theory, Locke answered the core problem "why people need government?" - purpose of establishing government to protect all people to have the right of life, freedom and property, and he called those rights as natural rights. If the government didn't serve for this goal, people had the right to deprive government power and overthrow the government. In Two Treatises of Government, he even 
thought that the main purpose of establishing government was to protect individual property right. He made such discussion: “Without the party's approval, the supreme power can't plunder any person's any part of property. This is because people shall enjoy property right now that protecting property is the purpose of government and also the purpose of people's joining the society; otherwise it is required to suppose that they lose the right as their purpose to join the society due to their joining the society. As for this irrational thing, no person is willing to do this.” [3]

The appearance of government is to protect people's natural right of life, freedom, and property. However, in the place with rights, there exists the possibility of abuse of power. Therefore, in order to prevent government's abuse of power and avoid people's natural rights to be damaged, it is very necessary to limit government power. An effective way of power limitation is to establish a limited government, that is, the separation of powers mentioned by Locke. Therefore, we link the Declaration of Independence with Locke’s theories together again.

\section{References:}

[1] George Anastaplo: Interpretation on American Constitution of 1787, translated by Zhao Xuegang, Beijing: Huaxia Publishing House, version 2012.

[2] Locke: The Second Treatise of Government, translated by Qu Junong and Ye Qifang, Beijing: Commercial Press, version 2010.

[3] Peter Lasleft: Introduction to Locke's Two Treatises of Government, translated by Feng Keli, Beijing: SDX Joint Publishing Company, version 2007

[4] Zhao Yifan: Historical Documents of the United States, Beijing: SDX Joint Publishing Company, version 1989 